\title{
Industry-Level Disparities in Antitrust Enforcement
}

\author{
Md. Mominul Islam ${ }^{1^{*}}$, Imrul Hossain Chowdhury ${ }^{2}$, Sabrina Islam ${ }^{3}$ \\ 1, 2, 3 Department of Economics, Jagannath University. Dhaka-Bangladesh \\ * Corresponding author: drmomin01@gmail.com
}

Article History
Received 2019-06-25
Revised 2019-08-03
Revised 2019-08-06
Accepted 2019-08-26
Published 2019-08-27
Keywords
Antitrust enforcement
Industry-level
Department of Justice Antitrust Division
Antitrust law
Concentration

\section{How to cite?}

Islam, M. M., Chowdhury, I. H., \& Islam, S. (2019). Industry-Level

Disparities in Antitrust Enforcement. SEISENSE Journal of Management, 2(5), 47-61. doi:

$10.33215 /$ sjom.v2i5.181

Copyright (C) 2019 The Author(s) (cc) BY
Abstract

Purpose- The purpose of this study is to analyze whether an increase in the concentration of industry causes an increase in the level of the Department of Justice Antitrust Division (DoJ)'s antitrust enforcement within that industry.

Design/Methodology- The study employed secondary data and quantitative research method was also utilized to achieve the objectives of the study. Multiple regression analysis techniques were used to analyze the data.

Findings- The results support the hypothesis that an increase in the concentration of industry causes an increase in the level of Department of Justice Antitrust Division (DoJ)'s antitrust enforcement within that industry. It appears that industry-level revenue from exports is highly correlated with the size of that industry and its lobbying activity.

Practical Implications- These results have practical relevance which helps to predict the intensity of antitrust activity in future years. Its practical implication is that there are disparities in antitrust enforcement that are influenced by factors other than concentration. By creating a benchmark that takes into account components such as this, the Department of Justice Antitrust Division (DoJ) can identify those companies who are likely to be engaging in anticompetitive behavior. 


\section{Introduction}

It is a big question "what alternative influences have an effect on antitrust enforcement". The research problem of this study is to find whether an increase in the concentration of industry causes an increase in the level of Department of Justice Antitrust Division (DoJ)'s antitrust enforcement within that industry (Willig, 1991). This paper considers the possibility that corporate lobbying may make antitrust regulators more lenient. Antitrust law is mostly unclear as to what actions organize anticompetitive behavior. This can be ascribed to reasons like the lack of specificity within the Sherman Act and the Clayton Act, as well as the varying interpretations of these acts by the court system (D. I. Baker, 1992).

In August of 2017, Google came under fire for its purported involvement in the ouster of Open Markets, a now-former division of the New America think tank that was known for its staunch opposition to corporate monopolies. That summer, Open Markets published a statement in support of the European Union's decision to levy a $\$ 2.7$ billion fine on Google for actions it deemed to be anticompetitive in the domain of internet search. In a story broken by Vogel (2017) at The New York Times. It was reported that Eric Schmidt, the executive chairman of Google's parent company, Alphabet Inc., complained to New America's leadership about Open Markets' statement. It was implied that this, coupled with Google's $\$ 21$ million in cumulative donations to New America, was what prompted the think tank to cut ties with Open Markets. Some experts argue that Google's lobbying efforts "help explain why mostly avoided damaging regulatory and enforcement decisions in the United States has" (Vogel, 2017).

The Google incident occurred two months after the release of congressional Democrats' "A Better Deal" platform, a key plank of which is American competition policy. A policy brief released in conjunction with the platform asserts that "permissive" regulation over the last thirty years has enabled a concentration of power by a select group of corporations. The paper cites the significant increase in the market share of the top four firms per industry as an impetus for updating U.S. "competition laws for the 21 st century".

The accusations against Google and Democrats' renewed attention toward corporate concentration raise the following questions: First, within the U.S., are there disparities in antitrust enforcement? Second, are these disparities a direct result of regulatory evasion by special interests (e.g., Google)? Finally, what are the economic effects of these disparities? This paper is a response to a perceived absence in the economics literature of research that considers the existence of favoritism by antitrust regulators. If such gaps do exist, it is important to identify what is causing them - lobbying is posited - and whether they have consequences for target industries. In this context, target industries are those toward which a preponderance of antitrust enforcement activity is directed. As is described in the literature review that follows, anticompetitive conduct poses significant costs on the national economy; thus, an examination of the current antitrust enforcement system may be necessary to ensure that the benefits of antitrust enforcement are not exceeded (Kauper, 1990).

To gather data on potential disparities in antitrust enforcement, it is consulted the website of the U.S. Department of Justice Antitrust Division (DoJ), on which case filings are published and categorized by industry. Thus, an industry-level approach is used to address my research questions. Additionally, the economic effects of antitrust enforcement are studied using data from the U.S. Census Bureau; metrics of interest include firm concentration and annual revenues, each of which is available on an industry-level basis. For lobbying data, it is used a dataset from the Center for Responsive Politics (CRP) that aggregates corporate political contributions. 


\section{Literature Review}

Antitrust laws are intended to protect customers from predatory corporate practices in order to ensure fair competition in an open-market economy (Rahl, 1974). These regulations were first created to check the abuses of immense "trusts" of the late 19th Century. Their main aim is to regulate the behavior and organization of business corporations for the benefit of consumers(Goyder, 1980).

According to Pitofsky, Patterson, and Hooks (2002), the effectiveness of antitrust laws is complex in nature to make judgment. The government is concerned with applying the antitrust laws to the companies or firms which are grown naturally. The antitrust laws are normally not been activated unless a firm having more than $60 \%$ of the market which is in a relevant model and there are proofs to the firm which is used to for the abusive manipulation to obtain or maintain its market control (Kauper, 1990).

It is observed that the ambiguity of antitrust law and lack of specific policy goals by antitrust regulators may contribute to differences in enforcement. Rubinfeld (2015) gives a historical overview of the intentions of regulators and the corporate actions that they deem to be unchallenged. Rubinfeld (2015) argues that the debate over the goals of antitrust enforcement is due to the broadness of the Sherman Act and the Clayton Act. In this study, it is identified two sections of the Sherman Act, promulgated in 1890, that came to serve as mandates for antitrust enforcement: Section 1, which forbids unreasonable restraints on trade, and Section 2, which illegalizes monopolies. The Clayton Act permits regulators to intervene when actions "substantially lessen competition" (Rubinfeld, 2015). The acts only provide "general principles" for antitrust enforcement, not precise definitions of what constitutes irrational corporate conduct. Congress has deferred interpretation of the statutes to the courts, which have often relied on the rule of reason analysis rather than per se analysis, "in which a practice is deemed illegal on its face" (Rubinfeld, 2015).

According to B. D. Wood and Anderson (1993), the government is not yet more conscious about antitrust laws and its enforcement; rather it should come clear at the antitrust mechanism and its enforcement so that there wouldn't be any violation. Although according to (D. P. Wood, 2004) US markets have seen large mergers and acquisitions, the competitive character has not yet diminished because of the regulatory framework adopted by the government. Here monopoly elements are always set aside and markets are allowed to work in a free environment with less intervention.

According to (Kovacic \& Shapiro, 2000), seminal changes have influenced antitrust enforcement activity. Recall that the Democrats cited an increase in lax antitrust enforcement that began during the 1980s in their platform. Kovacic and Shapiro (2000) write that during this era, it is clear that the courts, under the Chicago School's influence, were trimming back antitrust doctrine (Kovacic \& Shapiro, 2000). The "Chicago School" is a body of scholarship from the University of Chicago that advocates for free markets rather than government intervention (Rowley, 2005). Chicago economists argued that economies of scale were crucial for achieving allocative efficiencies because markets were naturally competitive, so any monopolies would erode over time due to new entrants.

Kovacic and Shapiro (2000) note that the Chicago mindset rose due to like-minded judicial appointments and the widespread belief "that U.S. firms were losing ground" on the international stage (p.53); the result was the soft implementation of antitrust law. In 1997, rules were corrected to allow for greater merger synergies, a tactic which "could make the law friendly to mergers in some cases" (Kovacic \& Shapiro, 2000).

It is said that competition benefits American consumers through lower prices, better quality and greater choice. However, it also maintains that increased competition reinforces American industry; thus, its mission appears to support the more general, total welfare view. Schwartz (1978), argues that the intentions are noneconomic in nature, such as enabling "alternative centers of power that could not be willingly marshaled 
behind authoritarian regimes". So, they have attempted to specify the goals of antitrust enforcement. However, Bork (1967) opposes that the primary goal of antitrust enforcement is allocative efficiency or that which maximizes consumer surplus. Rubinfeld (2015) claims that regulators evaluate mergers from both consumer welfare and total welfare points of view, in part because the courts are not clear as to which is the appropriate standard. This is confirmed by Armstrong and Sappington (2007) who note that most formal economic models assume that the aim of the regulator is to maximize a weighted average of both consumer surplus and the net profit of the firm. The DoJ, the regulator of interest in this paper, states on its website that its mission is to promote economic competition through enforcing and providing guidance on antitrust laws.

Changes in antitrust enforcement can have industry-level effects. J. B. Baker (2003) makes the case for antitrust enforcement using a series of natural experiments conducted since the implementation of the Sherman Act. For example, the U.S. Department of Transportation was responsible for reviewing airline mergers in the 1980s. Two particularly large proposals (Northwest-Republic and Ozark-TWA) were approved despite opposition from the DoJ; this is ostensible because federal antitrust enforcement was relatively relaxed during the second term of the Reagan administration. (John B. Taylor, an economist known for, among other things, the Taylor rule, writes on his blog that "the peak of the Chicago school influence was in the Reagan administration", as measured by the percentage of appointees to the Council of Economic Advisers from the University of Chicago.) Researchers found cases of higher airfares and reduced service quality following the approval of the deals. Baker concludes that without antitrust, firms can and do exercise market power, to the detriment of consumers and other buyers.

Furthermore, J. B. Baker (2003) shows that the benefits of antitrust enforcement exceed its costs. This researcher estimates that, as of 2003 , the total costs of antitrust enforcement are approximately $\$ 2$ billion per year; this number includes government outlays, litigation fees, and the opportunity costs of pursuing cases. This is contrasted with the benefits grew from preventing the exercise of market power, which is estimated to cost the national economy over $\$ 100$ billion per annum in deadweight loss. The author argues that the amount by which consumers are overcharged by monopolists "may or may not lead to an equivalent increase in consumer benefits". Instead, it may be used for rent-seeking activities, including "expenditures made on lobbying regulators to prevent entry" (J. B. Baker, 2003).

In a working paper, Fidrmuc, Roosenboom, and Zhang (2018) find that lobbying by individual acquirers before a merger announcement lead to more favorable antitrust enforcement outcomes. Specifically, they find that a one standard deviation increase in market cap-adjusted lobbying by an acquiring firm is associated with an increased probability that a merger review results in a favorable outcome, such as being unchallenged by regulators or expiration of the case under review. The differences between this research and mine, however, are that here it is intended to focus on industry-level lobbying and regulatory outcomes; additionally, Fidrmuc et al. (2018) limit their study to merger reviews. Mehta, Srinivasan, and Zhao (2017) find that "the power of an acquirer's judiciary committee representation is negatively and significantly related to the favorability of the antitrust merger review outcome. This suggests that politicians tasked with overseeing antitrust enforcement are vulnerable to lobbying by the constituent firm. The authors of the above papers have mainly emphasized on individual firms when analyzing the above influences on antitrust enforcement. In contrast to the industrylevel approach in this paper, Mehta et al. (2017) looked specifically at firms and their links to individual politicians. It seems, there is no paper that looks at the possible industry-level disparities in current antitrust enforcement. 


\section{Hypothesis}

As discussed in the literature review, antitrust law within the U.S. is largely ambiguous as to what actions constitute anticompetitive behavior. This can be attributed to reasons such as the lack of specificity within the Sherman Act and the Clayton Act, as well as the varying interpretations of these acts by the court system. Changes in antitrust administration can have industry-level impacts. It is said that the benefits of antitrust enforcement exceed its costs. So, it is logical to add antitrust enforcement. Lobbying by individual acquirers before a merger announcement lead to more favorable antitrust enforcement outcomes. However, section seven of the Clayton Act - one of the foundational statutes of antitrust law - directs regulators to intervene when the competition is substantially lessened (Rubinfeld, 2015). Most of the literature has focused on individual firms when analyzing the above influences on antitrust enforcement. The novelty of this paper relative to the existing research is its attempt to conduct such analyses at the industry-level. The value in a top-down approach is that it has the potential to direct regulators to industries in which anticompetitive behavior may pose a problem. This can result in a more proactive approach to antitrust enforcement, rather than waiting until merger reviews to make enforcement decisions. This corresponds to the mission of the DoJ, which is stated on its website to be the promotion of economic competition. Thus,

Hypothesis: An increase in the concentration of industry causes an increase in the level of DoJ antitrust enforcement within that industry (i.e., future antitrust enforcement should be initiated by anti-competitive behavior).

Control variables address the ongoing debate among economists over what alternative influences, if any, have an effect on antitrust enforcement. First, this paper considers the possibility that corporate lobbying may make antitrust regulators more lenient. J. B. Baker (2003) writes that the monopoly rents earned by concentrated firms via excessive prices can be used to engage in rent-seeking activities, including political contributions made with the intent to dissuade antitrust enforcement and erect barriers-to-entry. Other research has found that lobbying by individual acquirers before a merger announcement leads to more favorable antitrust enforcement (Fidrmuc et al., 2018). Additionally, Mehta et al. (2017) find that an acquirer's connections to congressional committees charged with antitrust oversight affect the favorability of merger reviews.

Other alternative influences may reflect geopolitical concerns or differing views on the role of antitrust enforcement among political parties. In regard to the former, Kovacic and Shapiro (2000) argue that the ascent of the Chicago School's lenient approach to antitrust issues during the 1980s can be attributed to the widespread belief at the time that U.S. firms were becoming less globally competitive. At the time, regulators risked ceding power to foreign countries by combating the market power of U.S. firms. The Reagan administration was particularly supportive of the Chicago School approach, as measured by the number of University of Chicago economists appointed to the Council of Economic Advisers during his two terms (Taylor).

\section{Methodology}

The quantitative research method was utilized to investigate the relationship between an increase in the concentration of an industry and an increase in the level of DoJ antitrust enforcement within that industry. This quantitative research is statistical in nature and has numbers attached to it. It deals with the study of numerical data (Bryman, 1984). It employs a mathematical hypothesis in the investigation of the quantitative phenomenon. Its function involves predicting outcomes and testing a hypothesis or theory. It draws a general and objective conclusion. The quantitative method is based on visible figures and numerical data. Analysis of numerical data helps the fact-based analysis of future trends and plays a very important role in the management decision-making process (Carr, 1994). The quantitative data analysis helps to develop the model 
that allows making the best choices among alternatives within the usual constraints of time and money (Newman, Benz, \& Ridenour, 1998).

\section{Data Collection and Processing}

It was used for secondary data. Advantages for the first source of secondary data are its authenticity, official recognition and widespread acknowledgment of the data. It was used because it was easily available (Szabo \& Strang, 1997). The secondary data I have used is free of costs. It was industry-specific, relevant and latest data It can be used to study the past trends and review of the literature (Hox \& Boeije, 2005).

The secondary data was collected from antitrust case filings from the DoJ identifies disparities in antitrust enforcement, biennial lobbying totals from the CRP serves as a proxy for regulatory evasion by special interests, and market concentration data from the U.S. Census Bureau determines the economic effects of any disparities. Based on the availability of data among these three sources, this paper focuses on the period of 2002 through 2017. Specifically, industry-level lobbying totals for the years 2002, 2006, and 2012 in combination with market concentration as measured in 2002, 2007, and 2012 attempt to explain antitrust enforcement disparities in the five-year periods that follow (e.g., from January of 2012 through December of 2016). It should be noted that the CRP only provides lobbying totals for even-numbered years; this is due to the U.S. federal election cycle, in which congressional elections occur every two years and presidential elections occur every four years (White-House, 2006). Thus, corporate lobbying in 2006 corresponds to market concentration in 2007. Variables to control for DoJ budget appropriations and industry-level exports use data from the DoJ and the U.S. Census Bureau respectively.

Antitrust case filings were collected from the DoJ's website, on which it catalogs all cases it initiates by open date and/or incident data, case title, case type (either civil merger, civil non-merger, criminal, or other), the federal court in which it was filed, and the industry code(s) for any firm(s) involved. Each filing includes links to case documents (e.g., legal briefs, plea agreements, etc.) that describe the nature of the action under review and the parties involved. Industry codes take the form of either a SIC code or a NAICS code, the latter of which was "adopted in 1997 to replace the [SIC] system" for the purpose gathering of data about the U.S. economy by federal agencies (United States Census Bureau). This paper focuses only on NAICS industry classifications because it is used by the U.S. Census Bureau to report industry-level data. Exhibit 1 shows the 20 distinct industry categories under the NAICS system (NAICS, 2015).

The 987 individual case filings are available for the years between and including 2002 and 2016. SIC codes were converted to their NAICS code equivalents using the SIC-to-NAICS crosswalk tool from the NAICS Association, and discretion was used to assign the appropriate NAICS code for those 58 observations with no industry code at all. The latter could prove to be a weakness of the data in the case that the assigned NAICS code is inaccurate; however, these observations represent a small portion of the overall dataset, and each NAICS code was assigned based on the best available information provided by each case filing and its corresponding documents (NAICS, 2015). For observations with multiple industry codes, only the primary code was kept to avoid double-counting, which could affect the weights given to each industry in the final analysis.

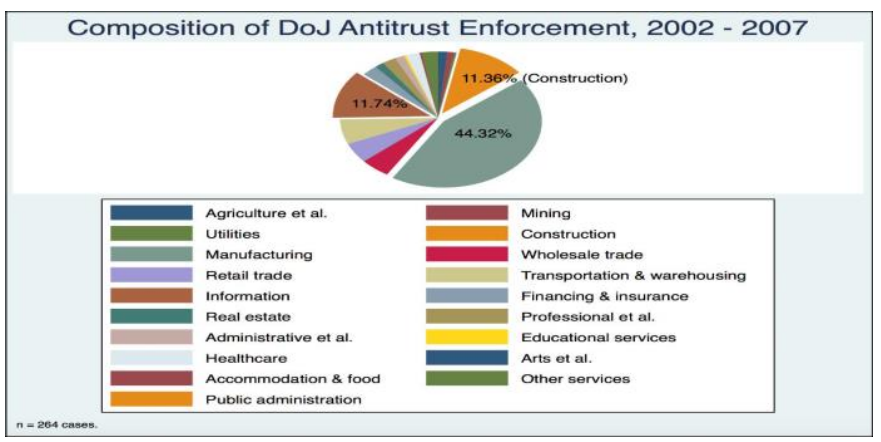

Figure 1 - Composition of DoJ Antitrust Enforcement, 2002-2007 


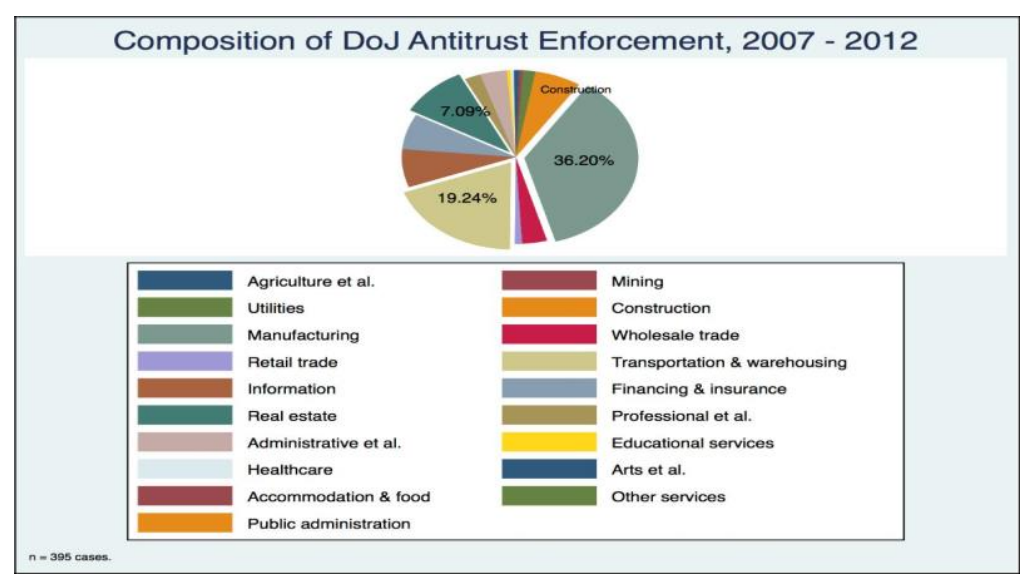

Figure 2 - Composition of DoJ Antitrust Enforcement, 2007-2012

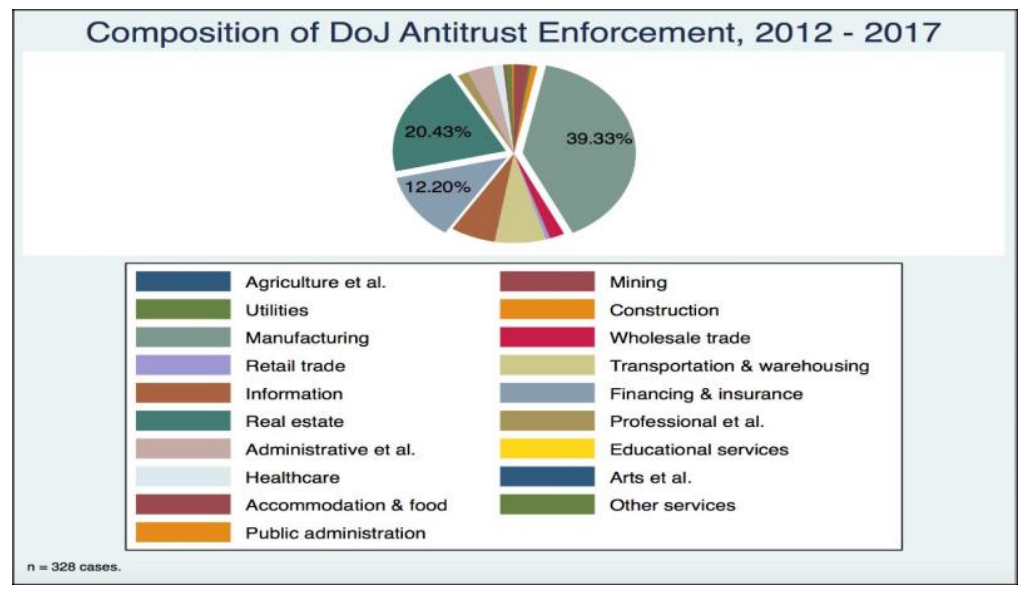

Figure 3 - Composition of DoJ Antitrust Enforcement, 2012-2017

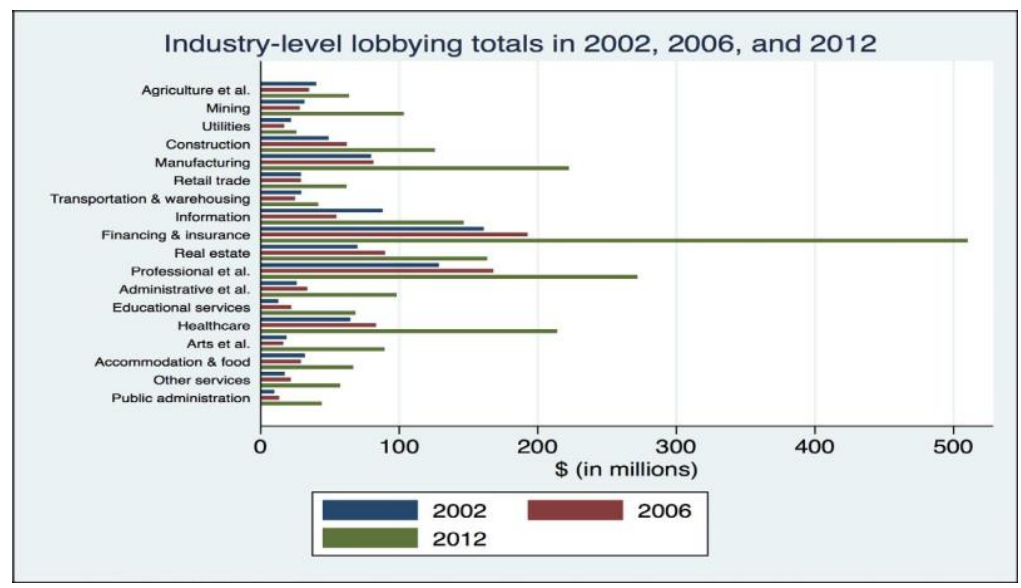

Figure 4 - Industry-level lobbying totals in 2002, 2006, and 2012

Figure 1 through 3 shows the composition of DoJ antitrust enforcement in three five-year periods. In the period ending 2007, the top three industries as a percentage of total cases filed ( $\mathrm{n}=264$ were Manufacturing (44.32\%), Information (11.74\%), and Construction (11.36\%). In the five-year period ending 2012, the top three industries as a percentage of total cases filed $(n=395)$ were Manufacturing $(36.20 \%)$, Transportation \& 
warehousing (19.24\%), and Real estate (6.55\%). In the five-year period ending 2017, the top three industries as a percentage of total cases filed $(\mathrm{n}=328)$ were Manufacturing $(39.33 \%)$, Real estate $(20.43 \%)$, and Financing \& insurance $(12.20 \%)$. It is interesting to note that the largest period-over-period change was in the Real estate: It increased by six times, from $1.52 \%$ in the period ending 2007 to $9.62 \%$ in the period ending 2012. This could perhaps be due to renewed attention to the industry following the housing crisis in 2008 . The mean percentage of DoJ antitrust enforcement for each period was 5.26\%.

Industry-level lobbying totals were collected from the CRP's website; on which it classifies political contributions given by about 100 defined interest groups. The CRP's dataset is unique in that it attempts to include contributions given by individuals who work for or are involved with industry; this is because corporations "are prohibited from making direct political contributions from their treasuries". Thus, the dataset reflects all of the information that individuals are required to disclose to the Federal Election Commission (e.g., employer), as well as contributions from each industry's political action committee. It should be noted that, although the data "are the most accurate numbers currently available", they are "conservative" estimates due to the number of contributions that are given with incomplete employer and/or occupation data (approximately 30\% in any given election cycle). Recent election cycles tend to have more complete data than earlier ones; however, the CRP has found that its data over the past twenty years "show a correlation between individuals' contributions and their employers' political interests". Those who give tend to be "top executives"; it is these individuals to whom the CRP pays "special attention" because they are "major or otherwise important donors" (The Center for Responsive Politics).

Because the CRP does not categorize according to NAICS codes, discretion was used to match each CRP industry to its NAICS counterpart (e.g., the CRP category for "Construction" was matched with the NAICS code for construction; interest groups in the CRP's "Agribusiness" category was matched with the NAICS code for Agriculture, Forestry, Fishing, and Hunting, etc.). 189 annual lobbying totals were collected on an industry basis for the years 2002, 2006, and 2012. Unfortunately, the CRP does not give separate wholesale trade from its associated industries; thus, there is no data for political contributions given by what NAICS classifies as the wholesale trade industry.

Figure 4 shows industry-level lobbying totals in 2002, 2006, and 2012. The top three industries were Financing \& insurance ( $\$ 160.93$ million), Professional et al. ( $\$ 128.53$ million), and Information ( $\$ 87.98$ million) in 2002; Financing \& insurance ( $\$ 192.54$ million), Professional et al. ( $\$ 167.77$ million), and Healthcare ( $\$ 83.20$ million) in 2006; and Financing \& insurance ( $\$ 510.17$ million), Professional et al. ( $\$ 271.82$ million), and Manufacturing (\$222.39 million) in 2012. The industry with the greatest increase in lobbying was Educational services, from $\$ 12.63$ million in 2002 to $\$ 68.32$ million in 2012.

Data tables featuring market concentration data were downloaded from the U.S. Census Bureau's American Fact Finder data platform. It should be noted that data was only available for the years 2002, 2007, and 2012. The resulting dataset is comprised of 41 observations for the revenue of the four largest firms per industry as a percentage of total industry revenue. For the manufacturing industry, the percentage of total value added by the four largest firms was used; the reason for this is "that it approximates the value created in the process of manufacture" and thus, is "the most satisfactory ensure of the relative economic importance" of manufacturing firm (Bureau, 2017). One weakness of the dataset is that there is no concentration data available for the following NAICS industries: Agriculture, Forestry, Fishing, and Hunting; Mining; Construction; and Public Administration. Finally, revenue concentration data was used in lieu of HHI; industry-level HHI measures that corresponded to NAICS codes could not be found for the years under consideration. 


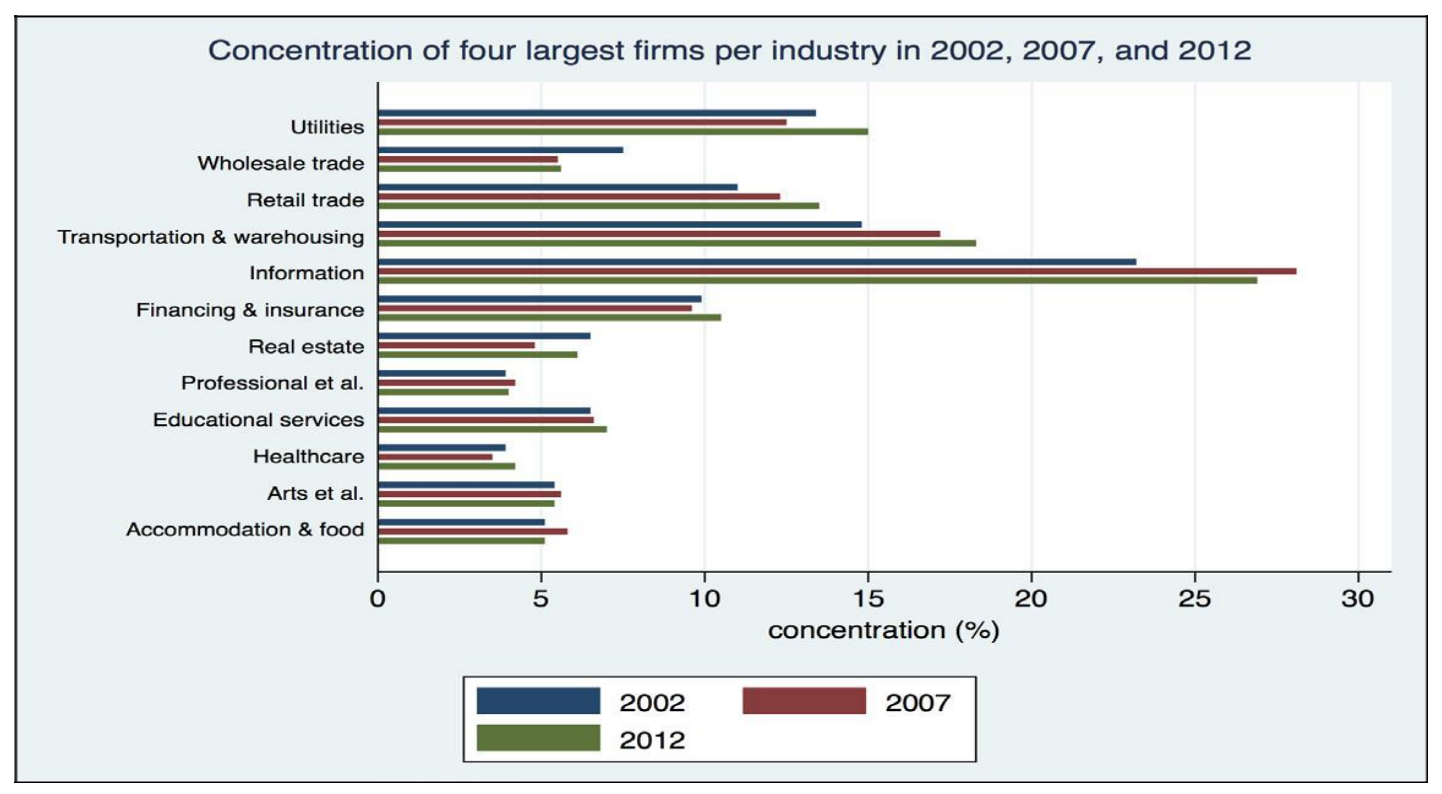

Figure 5 - Concentration of four largest firms per industry in 2002, 2007, and 2012

Figure 5 shows the composition of market concentration within and across industries in 2002, 2007, and 2012. The top three industries for all years were Information $(23.20 \%, 28.10 \%$, and $26.90 \%)$, Transportation \& warehousing $(14.80 \%, 17.20 \%$, and 18.30\%), and Manufacturing (13.40\%, 12.50\%, and 15.00\%). Market concentration generally increased. Only two industries Wholesale trade and Real estate - became less concentrated over the total period studied. The industry with the greatest increase in concentration was Retail trade, from $11.00 \%$ in 2007 to $13.50 \%$ in 2012. Perhaps this is due to the "Amazon Effect," or the phenomenon by which the significant disruption to the retail space caused by Amazon has forced traditional retail companies to become larger in order to compete.

\section{Data Analysis}

Multiple regression model was used to analyze the data to find the relationship between the independent and dependent variables. Multiple regression tries to relate one variable called dependent variable to be explained by one or more variables called explanatory variables. In multiple regression there has one dependent variable to be explained by other variables and this dependent variable cannot be used to explain other (DeFries \& Fulker, 1985).

\section{Econometric Model}

The above explanations for industry-level disparities in antitrust enforcement are incorporated into the following OLS regression models:

$$
\begin{aligned}
& d o j=\beta 0+\beta 1(\text { conc_4 })+\beta 2(\text { ln_lobbying })+\beta 3(\text { In_doj_funding })+\beta 4 \text { (party) }+\beta 5 \text { (ln_exports) ----------1 } \\
& \left.w t \_d o j=\beta 0+\beta 1 \text { (conc_4 }\right)+\beta 2(\text { In_lobbying })+\beta 3(\text { In_doj_funding })+\beta 4 \text { (party) }+\beta 5 \text { (In_exports) }---------2
\end{aligned}
$$

The dependent variable in both models is the number of antitrust enforcement cases initiated by the DoJ per industry. This number is presented as a percentage share of total cases in model 1 (" $\boldsymbol{d} \boldsymbol{o}$ )') and is weighted by industry size (i.e., total revenues as reported in 2002, 2007, and 2012 U.S. Census reports) in model 2 (“wt_doj"). The latter addresses whether antitrust enforcement increases or decreases in proportion to industry size. In both models, the period of time used was the five-year period including and following the 
year in which industry concentration figures were reported (e.g., concentration, as measured in 2002, is used to explain antitrust enforcement in the period from 2002 to 2007).

The main independent variable, "conc_4," measures the revenue of the four largest firms within an industry as a percentage share of industry size. It is used to represent industry concentration in the years 2002, 2007, and 2012.

"In_lobbying" represents the log of industry-level lobbying contributions. It should be noted that because the CRP only reports figures in even-numbered election years, corporate lobbying contributions in 2006 were used for observations taken in 2007.

"In_doj_funding" is the log of the dollar amount of total funding appropriated to the DoJ antitrust division in the year that precedes the five-year period used to calculate "doj" and "wt_doj." The intent was to analyze whether antitrust enforcement is driven by the number of resources that the DoJ has to devote to the due diligence process. It is expected that funding is positively correlated with antitrust enforcement activity. The data was obtained from the DoJ's website; on which it provides annual antitrust appropriations from 1903 to the present. It should be noted that DoJ appropriations do not vary by industry.

"In_exports" represents the log of revenue from exported goods and services received by firms within each industry. An industry with relatively high exports may be considered a "defensive" industry by the DoJ, or one that can increase the economic standing of U.S. companies relative to those in other countries.

Each of the preceding three variables was transformed as logs to normalize changes in dollar amounts as percentage changes. "In_lobbying" and "In_exports" were weighted by industry size to remain consistent with the dependent variable "wt_doj" in model 2. This accounts for the possibility that the extent to which industries engage in lobbying and generate exports is in proportion to their size.

"Party" is a dummy variable used to control for differing views on the role of antitrust enforcement among political parties. Democratic administrations were coded as 0 and Republican administrations were coded as 1.

An attempt was made to choose independent variables that are likely to have the greatest effect on industrylevel antitrust enforcement. However, omitted variable bias could result from the possibility that there are more influential factors beyond the four considered in this paper. Any omitted variable bias could also be due to gaps in the data for some industries. For example, the U.S. Census only provides industry-level export data for a select group of industries. It does not provide export data for industries including "Educational services" and "Healthcare and social assistance," both of which provide services to foreigners. Finally, multicollinearity could occur if independent variables such as lobbying and exported revenues are themselves a function of concentration.

\section{Results}

The results support the hypothesis that an increase in the concentration of industry causes an increase in the level of DoJ antitrust enforcement within that industry. In the highest-fit model (adjusted R2 $=0.48$ ), an increase of one percentage point in industry concentration results in an increase of 0.04 percentage points in an industry's share of total antitrust enforcement cases. Table 1 and Table 2 display results from five variations of models 1 and 2 , respectively. 
Table 1 - Effects on industry antitrust enforcement by DoJ as a share of total cases (\%)

\begin{tabular}{llllll}
\hline & $(\mathbf{A}) \mathbf{d o j}$ & $\mathbf{( B )} \mathbf{d o j}$ & $\mathbf{( C )} \mathbf{d o j}$ & (D) doj & (E) doj \\
\hline conc_4 & $0.269^{* *}$ & $0.294^{* *}$ & $0.286^{* *}$ & $0.286^{* *}$ & $0.482^{* *}$ \\
In_lobbying & $(0.100)$ & $(0.110)$ & $(0.113)$ & $(0.114)$ & $(0.186)$ \\
& & $1.906^{* *}$ & $1.720^{*}$ & $1.923^{* *}$ & $5.165^{* *}$ \\
In_doj_funding & & $(0.871)$ & $(0.853)$ & $(0.747)$ & $(1.945)$ \\
& & & 5.181 & 16.270 & 22.370 \\
party & & $(8.409)$ & $(14.770)$ & $(17.05)$ \\
& & & 2.642 & 1.615 \\
In_exports & & & $(3.152)$ & $(3.386)$ \\
& & & & $-2.700^{*}$ \\
Constant & & & & $-1.344)$ \\
& & & & & -453.800 \\
Observations & 1.324 & $(14.840)$ & $(156.700)$ & $(274.700)$ & $(314.600)$ \\
R-squared & $(1.180)$ & 33 & 33 & 33 & 16 \\
Adjusted R-squared & 36 & 0.241 & 0.247 & 0.266 & 0.493 \\
\hline
\end{tabular}

Robust standard errors in parentheses * $\mathrm{p}<0.10 * * \mathrm{p}<0.05 * * * \mathrm{p}<0.01$

Table 2 - Effects on industry antitrust enforcement by DoJ as a weighted share of total cases (\%)

\begin{tabular}{llllll}
\hline & (A) doj & (B) doj & (C) doj & (D) doj & (E) doj \\
\hline cone_4 & $0.009^{*}$ & $0.012^{* *}$ & $0.013^{* *}$ & $0.012^{* *}$ & $0.036^{* *}$ \\
In_lobbying & $(0.005)$ & $(0.005)$ & $(0.005)$ & $(0.005)$ & $(0.016)$ \\
& & $0.114^{* *}$ & $0.115^{* *}$ & $0.118^{* *}$ & $0.456^{* *}$ \\
In_doj_janding & & $(0.049)$ & $(0.047)$ & $(0.047)$ & $(0.201)$ \\
party & & -0.126 & 0.474 & 1.695 \\
& & $(0.522)$ & $(0.867)$ & $(1.552)$ \\
In_exports & & & 0.136 & 0.301 \\
& & & $(0.194)$ & $(0.278)$ \\
Constant & & & & $-0.239^{*}$ \\
& & & & $(0.126)$ \\
Observations & $0.217^{* *}$ & $-1.539 * *$ & 0.802 & --10.610 & --34.260 \\
R-squared & $(0.094)$ & $(0.667)$ & $(10.060)$ & $(16.510)$ & $(29.150)$ \\
Adjusted R-squared & 36 & 33 & 33 & 33 & 16 \\
\hline
\end{tabular}

Robust standard errors in parentheses * $\mathrm{p}<0.10$ ** $\mathrm{p}<0.05$ *** $\mathrm{p}<0.01$

$\beta 1$ is approximately 0.27 in model $1-A$. This indicates that an increase of one percentage point in industry concentration ('conc_4') results in an increase of 0.27 percentage points in an industry's share of total antitrust enforcement cases. In models $1-\mathrm{B}, 1-\mathrm{C}, 1-\mathrm{D}$, and $1-\mathrm{E}, \beta 1$ is approximately $0.29,0.29,0.29$, and 0.48 , respectively. In model 2 , the coefficient estimates for models $2-\mathrm{A}$ through 2 -E are $0.01,0.01,0.01,0.01$, and 0.04 , respectively. The smaller effect suggests that antitrust enforcement is largely in proportion to an industry's size: In model 2-A, an increase of one percentage point in industry concentration results in an increase of 0.01 percentage points in an industry's share of total antitrust enforcement cases after adjusting for industry size. 
$\beta 2$ is approximately 1.91 in model $1-B$. This indicates that an increase of one percentage point in industrylevel lobbying totals (“(wt) In_lobbying") results in an increase of 0.02 percentage points in an industry's share of total antitrust enforcement cases. In models $1-\mathrm{C}, 1-\mathrm{D}$, and 1-E, $\beta 2$ is approximately 1.72, 1.92, and 5.17 , respectively. In model 2 , the coefficient estimates for models $2-\mathrm{B}$ through 2 -E are $0.11,0.12,0.12$, and 0.46 , respectively.

$\beta 3$ is approximately 5.18 in model 1-C. This indicates that an increase of one percentage point in DoJ budget appropriations ("In_doj_funding") results in an increase of 0.05 percentage points in an industry's share of total antitrust enforcement cases. In models 1-D and 1-E, $\beta 3$ is approximately 16.27 and 22.37, respectively. In model 2, the coefficient estimates for models $2-\mathrm{C}$ through $2-\mathrm{E}$ are $-0.13,0.47$, and 1.70 , respectively. The coefficient estimate in model 2-C is negative, which suggests that increases in DoJ funding during the period did not result in an increase in industry-size-adjusted antitrust enforcement until the presidential party is adjusted for. Perhaps the DoJ is more efficient under Republican administrations, such that there is a larger increase in cases filed for each change in DoJ funding relative to comparable changes under a Democratic administration.

$\beta 4$ is approximately 2.64 in model 1-D. This indicates that a Republican administration ("party") results in an increase of 2.64 percentage points in an industry's share of total antitrust enforcement cases. In model 1-E, $\beta 4$ is approximately 1.62. In model 2 , the coefficient estimates for models $2-\mathrm{D}$ and $2-\mathrm{E}$ are 0.14 and 0.30 , respectively. This is in contrast to what is suggested by the economic literature, which points to the Republican Party's laissez-faire approach to the economy as being conducive to anticompetitive behavior.

Finally, $\beta 5$ is approximately -2.70 in model $1-\mathrm{E}$. This indicates that an increase of one percentage point in industry-level exports (“(wt) In_exports") results in a decrease of 0.03 percentage points in an industry's share of total antitrust enforcement cases. In model 2, the coefficient estimate for model 2-E is -0.24 . The negative relationship between antitrust enforcement and an industry's level of exports is consistent with economic theory: Relatively high exports ensure that defensive industries (or those that provide a geopolitical advantage to the U.S.) maintain their market power.

The positive relationship between antitrust enforcement and the industry concentration is also consistent with what is expected by consensus: Although the main antitrust statutes generalize as to what should be considered anticompetitive behavior, a decrease in competition from concentration should be pursued from an antitrust perspective. However, the positive relationship between antitrust enforcement and lobbying totals challenges previous economic research, which suggests that lobbying extracts economic rents from regulators in the form of leniency.

Each of the coefficient estimates for "conc_4," “(wt_) lobbying," and "(wt_) exports" are statistically significant in both models. Neither "doj_funding" nor "party" are statistically significant, which is likely due to the lack of observable variance in those variables: "doj_funding" is the same for all industries in each year (although it varies from 2002 to 2007 and 2012) and there were only two presidents in office during the period studied.

Model 2-C provides the best fit overall as measured by an adjusted $R^{2}$ of 0.48 . This indicates that after adjusting for industry size, industry-level concentration, lobbying totals, and revenue from exports explains $48.00 \%$ of the variance in antitrust enforcement. Comparison to model 1 - C, which has an adjusted $R^{2}$ of approximately 0.17 , implies that industry size accounts for about $17.00 \%$ of the variance in antitrust enforcement after controlling for the aforementioned variables.

$\beta 1$ is lowest in models $1-A$ and $2-A$, which suggests that these regression specifications exhibit negative omitted variable bias such that the effect of “conc_4' on "(wt_) $\boldsymbol{d o g}^{\prime}$ ” is under-estimated. This problem is 
addressed with the subsequent addition of control variables. $\beta 1$ decreases from 0.294 in model 1-B to 0.286 in model 1-C and from 0.013 in model 2-C to 0.012 in model 2-D. It is possible that the effect of "conc_4" is over-estimated in model 1-B before the inclusion of "In_doj_funding" and in model 2-C before the inclusion of "party." The increase in most coefficient estimates after the inclusion of "In_exports" in models $1-\mathrm{E}$ and $2-\mathrm{E}$ suggests that the protection of defensive industries is an influential consideration in antitrust enforcement.

Table 3 - VIF value

Model 1

\begin{tabular}{|c|c|c|c|c|c|}
\hline & VIF & 1/VIF & & VIF & 1/VIF \\
\hline conc_4 & 2.61 & 0.38 & conc_4 & 2.56 & 0.39 \\
\hline In_lobbying & 3.69 & 0.27 & In_lobbying & 7.65 & 0.13 \\
\hline In_doj_funding & 2.82 & 0.35 & In_doj_funding & 2.81 & 0.36 \\
\hline Party & 3.25 & 0.31 & Party & 3.02 & 0.33 \\
\hline In_exports & 4.61 & 0.22 & In_exports & 9.65 & 0.10 \\
\hline
\end{tabular}

As indicated by Table 3, multicollinearity does not appear to be an issue in model 1; the highest VIF value is 4.61 for "exports" in model 1-E. However, there appears to be an issue with multicollinearity in model 2; the highest VIF value is 9.65 for "wt_exports" in model 2-E. It appears that industry-level revenue from exports is highly correlated with the size of that industry and its lobbying activity. It is a possibility that corporate lobbying predicts future antitrust enforcement because it enables those firms to achieve greater market power in the interim which leads to regulatory action later on. Thus, avenues for future research include whether foreign revenues and political contributions enable the industry to grow larger and vice-versa.

\section{Conclusions and Policy Implications}

These results have practical relevance for policymakers, who can use them to predict the intensity of antitrust activity in future years. For example, if concentration within the 'Information' industry increases by $5.00 \%$ in 2020, antitrust enforcement within that industry can be expected to increase by up to approximately 0.18 percentage points. Thus, the DoJ may hire additional attorneys to handle a larger caseload and Congress may appropriate the funding needed in order to do so. This practice would be particularly conducive to a costbenefit analysis, as policymakers could compare the marginal cost of DoJ due diligence to the creation of total surplus (e.g., lower prices for consumers, small business growth, etc.).

Additionally, policymakers should take note of the effect of corporate lobbying and exports. This paper suggests that any industry concentration enabled by lobbying is eventually addressed by the DoJ; however, policymakers should consider measures that work to preempt this mechanism entirely. One possibility is to limit members of Congress with significant corporate constituencies from serving on the two congressional subcommittees on antitrust law. Similar prudence can be extended over the selection of an Assistant Attorney General to oversee the antitrust division of the DoJ. Because this individual must be nominated by the President and confirmed by the Senate, special attention should be given to ensure that third parties do not have undue influence on this process. Separately, the negative relationship between industry-level antitrust enforcement and revenue from exports indicates that regulators are lenient toward domestic companies that do business globally. As a response, policymakers should consider providing support to entrepreneurs and small companies who are attempting global operations. By doing so, these businesses may be better able to compete with large competitors. 
Overall, the main policy implication from this work is that there are disparities in antitrust enforcement that are influenced by factors other than concentration. One way this can spur action is to use an industry's lobbying activity as a measure of its market power. By creating a comprehensive benchmark that takes into account components such as this, the DoJ can better identify those companies who are more likely to be engaging in anticompetitive behavior.

Alternatively, policymakers may need to reassess the true goal of antitrust enforcement or craft new antitrust law that specifies what constitutes anticompetitive behavior in the modern era. In either case, the narrowing of the gap between the stated goal of antitrust enforcement (i.e., increased competition) and the actions of antitrust enforcement serves as a better signal to corporations when making merger and acquisition decisions. Such decisions can benefit from the finding that political contributions do not necessarily dissuade regulators from reviewing potentially anticompetitive transactions.

Funding: This research received no external funding

Acknowledgments: The authors acknowledge the support of the Department of Economics, Jagannath University. Dhaka-Bangladesh

Conflicts of Interest: The authors declare no conflict of interest.

\section{References}

Armstrong, M., \& Sappington, D. E. (2007). Handbook of Industrial Organizationchap. Recent Developments in the Theory of Regulation, 1557-1700.

Baker, D. I. (1992). Antitrust and Politics at the Justice Department. JL \& Pol., 9, 291.

Baker, J. B. (2003). The case for antitrust enforcement. Journal of Economic perspectives, 17(4), 27-50.

Bork, R. H. (1967). The goals of antitrust policy. The American Economic Review, 57(2), 242-253.

Bryman, A. (1984). The debate about quantitative and qualitative research: a question of method or epistemology? British journal of Sociology, 75-92.

Bureau, U. S. C. (2017). Census Data. Retrieved 25 August, 2019, from https://www.census.gov/data.html

Carr, L. T. (1994). The strengths and weaknesses of quantitative and qualitative research: what method for nursing? Journal of advanced nursing, 20(4), 716-721.

DeFries, J. C., \& Fulker, D. W. (1985). Multiple regression analysis of twin data. Behavior genetics, 15(5), 467473.

Fidrmuc, J. P., Roosenboom, P., \& Zhang, E. Q. (2018). Antitrust merger review costs and acquirer lobbying. Journal of Corporate Finance, 51, 72-97.

Goyder, D. (1980). The Antitrust Laws of the United States of America: A Study of Competition Enforced by Law: Cambridge [Eng.]; New York: Cambridge University Press.

Hox, J. J., \& Boeije, H. R. (2005). Data collection, primary versus secondary.

Kauper, T. E. (1990). The Justice Department and the Antitrust Laws: Law Enforcer or Regulator? The Antitrust Bulletin, 35(1), 83-122.

Kovacic, W. E., \& Shapiro, C. (2000). Antitrust policy: A century of economic and legal thinking. Journal of Economic perspectives, 14(1), 43-60.

Mehta, M. N., Srinivasan, S., \& Zhao, W. (2017). Political influence and merger antitrust reviews. Available at SSRN 2945020.

NAICS. (2015). 2017-2022 SIC to NAICS Crosswalk. Retrieved 25 August, 2019, from https:/ /www.naics.com/wp-content/uploads/2014/10/SIC-to-NAICS-Crosswalk.pdf?.

Newman, I., Benz, C. R., \& Ridenour, C. S. (1998). Qualitative-quantitative research methodology: Exploring the interactive continuum: SIU Press. 
Pitofsky, R., Patterson, D., \& Hooks, J. (2002). The essential fecilities doctrine under us antitrust law. Antitrust LJ, 70, 443.

Rahl, J. A. (1974). Foreign Commerce Jurisdiction of the American Antitrust Laws. Antitrust Law Journal, 43(3), 521-529.

Rowley, C. K. (2005). An intellectual history of law and economics: 1739-2003. 2005), The Origins of Law and Economics. Essays by the Founding Fathers, Cheltenham u. a.(Edward Elgar), 3-32.

Rubinfeld, D. L. (2015). Antitrust Policy: Lessons from the US.

Schwartz, L. B. (1978). Justice and other non-economic goals of antitrust. U. Pa. L. Rev., 127, 1076.

Szabo, V., \& Strang, V. R. (1997). Secondary analysis of qualitative data. Advances in nursing science, 20(2), 66-74.

Vogel, K. P. (2017). Google Critic Ousted From Think Tank Funded by the Tech Giant. Retrieved 25, August, 2019, from https://www.nytimes.com/2017/08/30/us/politics/eric-schmidt-google-new-america.html

White-House. (2006). Elections \& Voting. Retrieved 25 August, 2019, from https://www.whitehouse.gov/about-the-white-house/elections-voting/

Willig, R. D. (1991). Antitrust Lessons from the Airline Industry: The DOJ Experience. Antitrust LJ, 60, 695.

Wood, B. D., \& Anderson, J. E. (1993). The politics of US antitrust regulation. American Journal of Political Science, 1-39.

Wood, D. P. (2004). The US Antitrust Laws in a Global Context. Colum. Bus. L. Rev., 265. 